\title{
Internalization of Speech: Pronunciation and Perception of the Word
}

\begin{abstract}
AKANE SAITO
JSPS-Fellow, Kyushu University, Japan (nekonokuni85@yahoo.co.jp)

There are various philosophers who have discussed the role of language in ancient India. Among them, Bhartrhari considered the relation between the superficial appearance of speech and its essential nature. In actual life, we pronounce and perceive the word. He beld that there must be some link between ideal logic and worldly truth. His focus in the Brabmakanda of the Väkyapadiya, is on the process of communication, the process of the internalization of speech. He differentiates the perspective of the speaker and the hearer, and explains the movement of sounds. The sphota theory addresses both how to pronounce the word and how to perceive it. Traces of his discussion are found in the works of his follower Mandanamiśra in his book, Sphotasiddhi.
\end{abstract}

Keywords: Indian philosophy on language; Bhartṛhari; Vākeyapadīya; Maṇḍanamiśra; Sphotasiddhi

\section{$1 \quad$ Introduction}

In this paper, I focus on the medium of linguistic communication, which has been discussed in detail in the history of Indian philosophy. We all know that we understand things because they have been told to us linguistically. But which aspect of language exactly is responsible for the communication of a given meaning? The uttered sounds? Their internalized form? An abstract entity evoked by them? Different authors have different answers to this question. The grammarian Patañjali (2 BCE), who commented on the great grammar work of Pạnini (4 BCE), defined the concept of the word (sabda) in his Mabäbhäsya (MBh). Bhartrihari (5 CE), who is probably the most influential philosopher as well as grammarian in medieval times, followed Patañjali and greatly developed the discussions in his Väkyapadiya (VP). Bhartrihari considers phonemes both superfluous, since sounds are enough to convey a meaning, and not sufficient, since they have no connection with a meaning. Instead, he postulates a complex structure, with sounds at first and then sphota, which is the nature of the word. His deep investigation on sounds divides sounds in accordance with their attribution: the speaker's speech-organ and the hearer's auditory faculty. The philosopher Maṇdanamiśra (Maṇdana) (7-8 CE) is the follower of Bharț̣ari. Maṇana has examined in his Sphotasiddhi (SS) the process of the manifestation of sphota, in other words the process of perception of the word, thus relating Bhartrhari's language theory to the epistemology of the Vedānta school of Indian philosophy. Sphota is interpreted by Mandana clearly as that of the word coming from the external world, namely as that which is perceived by the hearer. However, Mandana does not have much to say about the internal aspect, namely the speaker's side, while Bhartrihari clearly distinguishes the internal (the speaker's) and the external (the hearer's), as we can

Journal of World Philosophies 2 (Summer 2017): 109-120 
see in his distinct use of the terms näda and dhvani, which elsewhere are used synonymously to mean sound of any kind. The understanding of meaning, whether as speaker or as hearer, is necessarily related to our consciousness. That is, at some point the word exists in our minds. Nonetheless, there is as yet no clear account of the process of its internalization.

In this paper, I will consider two questions:

1) what exactly is the difference between the external and the internal aspects of the word for Bhartrinari and Mandana, and

2) how does the Grammarians' theory of language explain the process of the internalization of speech. ${ }^{1}$

I will proceed as follows: In section 2, I will illustrate the relation between sound and the word, and try to show the basic structure of the word using the Grammarians' discussion as a clue. In section 3, I will focus on Bhartrihari's sphota theory and try to show how he defined sound. Finally, in section 4, I will illustrate how Maṇdana discussed the manifestation of sphoța in his SS and how he followed Bhartṛhari’s discussion.

\section{Previous Studies on Sphoța}

K. A. Subramania Iyer composed a full annotated English translation of the SS in 1966 (Iyer [1966]), published in Deccan College Post-graduate and Research Institute of Poona. Before this work, he had published an article dealing with the sphota theory in the history of Grammar from Pānini to Maṇdana (Iyer [1947]), and this is the basis on which his full translation rests. Among his many significant contributions to the study of the Grammarians' philosophy, of particular importance to this thesis is his multi-volume edition and translation of the VP. He is certainly the foremost pioneer in this recondite field. ${ }^{2}$

As for the relation between sphota and sound (näda/ dbvani), there is not so much research. Especially the pre-modern Grammarians after Mandana changed the concept of sphota slightly and did not discuss it in relation with sounds. ${ }^{3}$ However, although they did not discuss the difference between nāda and dhvani, John Brough (1951) and Iyer (1965) showed us in detail the aspect of sound (dhvani) of the word. ${ }^{4}$ Especially Brough's criticism about highlighting the mystique of sphota is quite accurate.

\section{2 \\ Relation between Sound and the Word: Core of the Word}

First of all, we should know how the word and the sound are defined by the ancient Grammarians and differ from each other. There are two meanings of the word śabda proposed by Patañjali: "the word" which makes the meaning understood, and "physical sound." 5 These two simple definitions, however, might be misleading. This is because in Patañjali's MBh on the Asțädhyāyz (A) 1.1.70, he says "sphota is sabda, and sound is the property of sabda." Here sound (dhvami) is an external phenomenon of sabda, and there is an internal aspect to which its sound is subservient, namely sphota, that which reveals the sound's "meaning" to the mind. Sphota is an unchangeable entity, which is generally related to the meaning (referent). However, since Patañjali said that even the beating of the kettle-drum brings about sphota, "the meaning" cannot be taken simply. According to Pānini's Grammatical rule, the word's primary referent is related to its own form (svarūpa). ${ }^{7}$ In the Grammatical system, the word is the signifier and therefore necessarily related to some referent. 
Pānini stated in the above rule that if it is not yet related to some other object as its meaning, its own word- or sound-form (śabdasvaruppa) is the primary referent. Regarding this issue, Haradatta, who is a Grammarian in medieval times (7-8 CE), interpreted the word's own form (sabdasvarüpa) as the universal (sämānya: generic concept) of different individual variations of one word. ${ }^{8}$ The word agnih can be pronounced in different ways, namely by different tones, tempos and so on, but it has its own essential form which is the basis of all the variations. Its own word- or sound-form is its most essential 'referent' (väcya: meaning to be referred). And, I say it is this (inner and essential) form of the word or sound that is sphota. All of the words consist of their own word-form (svarüpa = samannya) and modalities which make them appear differently. Therefore, every word has sphota as the core of its existence. The same thing is claimed also by Bhartrhari using the concept of "the word's generic form" (śabdākrti). ${ }^{9}$ Both are not the actual (or superficial) form of the word but that which is perceived as its true nature though decorated by sounds. And accordingly, the previous definitions of śabda change slightly:

[Condition 1] When the linguistic convention of a śabda is known,

[1] The śabda is connected both with its own form (svarüpa $=\bar{a} k$ rti $=$ sphota $)$ and with its meaning. Such a śabda is equivalent to pada or väkya, namely "the word."

[Condition 2] When the linguistic convention of a śabda is not known,

[2] The śabda is connected only with its own form (svarüpa $=\bar{a}$ kerti $=$ sphota $)$. Such a śabda is merely dhvani "sound."

Sphoța Theory of Bharț̣hari

The concept of sphota is developed from the idea of sabda in the MBh. Although Patañjali himself did not give a clear explanation of sphota, Bhartrhari refined this into an elaborate philosophical theory in the VP. After Patañjali's examination of śabda, the Grammarians, including Bhartṛhari, no longer gave any importance to the "phoneme" (varna). Instead, sound (dhvani) was emphasized as the cause of manifestation of the word (sabda, more precisely sabdasvaruppa $=$ sphota), beginning, it seems, with Bhartṛhari.

\section{Accumulation of Sounds: External and Bodily Sounds}

Bhartrihari has differentiated the usage of the terms dhvani and nāda. According to his explanation in the auto-commentary on I.47, dhvani is the external sound which pervades the space (vyoman) and is the fundamental cause of the manifestation of sphota. On the other hand, näda is the internal form of sound (= bodily resonance) which has been accumulated by the speech-organ. Let us start with the following verse ${ }^{10}$ :

\section{VP I.47 (p. 105, 11.1-2):11}

The [conceptual word (=sphota)], ${ }^{12}$ which has been ascertained (vitarkita) by the intellect before [the utterance] and which has been made to reside (nivesita) in a particular meaning (= 
a word-form is assigned to a particular meaning), is seized (anugrah) through sound (dhvani) which has been transformed (vivrtta) [into bodily resonance] by the speech organs.

The content of this verse is split into two phases: 1) the process of residence, namely, pervasion (vyävesa) by the word-form of the referent (I.47ab), and 2) the process of pronunciation (I.47cd). And as for the second phase, the process of the actual pronunciation of the word is explained by Bhartṛhari as follows:

Auto-commentary on I.47 (p. 105, 1.6-p. 106, 1.3):13

Regarding "which has been transformed by the speech organs" [in the verse]. Indeed, the reality of the word (śabdatattva) which is not characterized by the transformation (vikriya) is transformed according to the external sound (dbvani) which is characterized by the transformation. Then when the subtle external sound, which pervades [the ether], is accumulated by the function of the [speech-]organ, it has been transformed as the gross bodily resonance (nāda) which is the object of perception just like a cloud compacted [by the wind], [and] the untransformable [word itself] is grasped as if it is transformed by imitating the transformation [into bodily resonance].

Here dhvani, if it pervades everywhere, should be also inside our body. In that sense, the translation "external sound" is not precise. Regardless of this danger, I keep translating it as "external sound" in order to differentiate from sphota as well as nāda. Those subtle, external sounds are developed/transformed into the gross bodily resonances when accumulated by the speech-organ. As we can see from the term "before [the utterance]," this is the explanation of how to pronounce the word. The word is manifested by the subtle, external sounds which have been transformed into the gross, bodily resonances. Subtle, external sounds are pervasive but imperceptible, while gross bodily resonances are perceptible. Pronunciation is the process in which the speech-organ accumulates subtle external sounds and transforms them into the perceptible entities. And because of the sequentiality of bodily resonances, Bhartrhari explains, we feel that the word is sequential. ${ }^{14}$ The bodily resonances appearing inside the speaker manifest sphota. That means, in the case of the speaker, that there is a causal relationship between the bodily resonances and sphota. And since the bodily resonances have their own sequence, sphota is affected by this and appears to be sequential, although in reality it has no sequence. This is because sphota is single and fixed (nitya).

\section{Classification of External Sounds and Bodily Resonances}

Now another question arises: how exactly are dhvani and nāda different? In the following definitions of Bhartṛhari, we find there are two classifications in both of them, namely primary and secondary. 15

\section{Classification of External Sounds}

External sounds are first defined by Bhartrhari as subtle particles pervading the ether. How, then, does he think of actual sound, which is also called dhvan? In the following passages, 
Bhartrhari proposes two kinds of dhvani, both of which are actual sound, distinct from any imperceptible entity: primary, external sound and secondary, external sound.

VP I.75 (p. 140, 11.9-10):16

[The Grammarians] explain (pracaks) the difference of the mode (vrtti) of sphota, whose duration is not differentiated [but] which is subsequent (anupatin) to the time [of the pronunciation] of sounds, by means of the distinction of the limiting factor (upādhi) of [the intellect which] grasps [sphota] (or 'of the different limiting factors that are [sounds by which sphota] is grasped').

First of all, we notice that the word grahana "grasping" is used here. So we should change our perspective from the speaker to the hearer. And accordingly, dhvani is taken as the sound to be perceived, in total contrast to nāda which is the sound to be uttered. Just like the bodily resonances affect sphota when the speaker pronounces the word, now the external sounds play the same role: they affect sphota when the hearer perceives the word.

Auto-commentary on I.76 (p. 142, 1l.1-3): ${ }^{17}$

In the duration of the fixed (nitya) things, there is no function of the capacity of time as assistant. As for all these sphotas, those we call varnasphota, padasphota, and väkyasphota, in mundane reality they do have a nature that is tracked by the intellect between two limits, prior and posterior. But [in reality] there is no difference between them as to duration, regardless of how large or small they are. They do not have different durations [themselves]. But when we become aware of them, we falsely attribute to them the duration of our perception of them. Regarding "the time of operation as well as that of one's own" [in the verse]: The primary bodily resonance is that of which form of duration is superimposed, due to the non-distinction [between the dhvani and the sphota], onto the body of the word, and which is the cause of establishing the worldly cognition/expression regarding the distinction of time of short, long, and prolated vowel. On the other hand, the secondary bodily resonance brings about the respective establishment of external time of conditions such as fast.

Each word exists without the delimitation of time or size. We generally feel that the time required to pronounce gaub is shorter than that required for devadattah, but such a difference of size is not of the word's own form but is caused by the primary sound. The primary, external sound is referred to by the Grammarians as the cause of the manifestation of sphota. On the other hand, the secondary sound is the cause of the differences in intonation, pitch, accent, or tempo ( $=$ vrtti: any kind of modality). We can readily understand that the physical sound or tone that differentiates a word is considered to be secondary. The modality of the secondary sound is the cause of continuous perception (prabandhanimitta), and it ensures the continuity of manifestation of sphota. This whole discussion, however, is limited to the side of the hearer. After perceiving the word together with the sound, sphota becomes manifest in the hearer's mind. But the perception of the word is inevitably influenced by the external sounds, which have been the bodily resonances on the side of the speaker. 


\section{Classification of Bodily Resonances}

Bodily resonance is also divided into primary (präkrtanāda) and secondary (vaikrtanäda). And we find that the explanation of these two is almost the same as that of the classification of the external sound:

Auto-commentary on I.101 (p. 166, 1.3-p. 167, 1.2):18

In the duration of the fixed (nitya) things, there is no function of the capacity of time as assistant. As for all these sphotas, those we call varnasphoța, padasphota, and väkyasphota, in mundane reality they do have a nature that is tracked by the intellect between two limits, prior and posterior. But [in reality] there is no difference between them as to duration, regardless of how large or small they are. They do not have different durations [themselves]. But when we become aware of them, we falsely attribute to them the duration of our perception of them. Regarding "the time of operation as well as that of one's own" [in the verse]: The primary bodily resonance is that of which form of duration is superimposed, due to the non-distinction [between the dhvani and the sphota], onto the body of the word, and which is the cause of establishing the worldly cognition/expression regarding the distinction of time of short, long, and prolated vowel. On the other hand, the secondary bodily resonance brings about the respective establishment of external time of conditions such as fast.

Now, we encounter the problem that the explanations of these two bodily resonances also refer to the state of perception (upalabdhi), and if we take this perception as the hearer's perception, $d b v a n i$ and näda would be identical. Therefore, in order to keep logical consistency, this perception is to be taken as that of the speaker. Maybe taking it in this way works: as the deaf person's speaking difficulties show, some aspect of perception is also required for a speaker.

Here, I propose that we can understand näda ('bodily resonance') as the sound on the side of the speaker, while dhvani ('external sound') as that on the side of the hearer. This understanding is different from the last I.47: there dhvani is the subtle external sound pervading the ether, while $n \bar{a} d a$ is the gross bodily resonance transformed from dhvanis. Contrast between dhvani and nāda is on the one hand 'subtle' and 'gross,' and on the other hand 'the hearer's side' and 'the speaker's side.' But a common feature exists between the two. Namely, nāda is always related to the body or pronunciation in the speech-organ, and dbvani is related to outside the body or perception of the external world. So Bhartrihari's usages are consistent, even though he introduces hereafter different opinions about the word and sound, some of which take these concepts differently, which certainly means that such definitions of sounds were controversial even in his times.

\section{Manifestation of Sphota}

Another question arises: how do we know sphota? Or do we really perceive the aspect of sphota in the word? Bhartrhari thought, I surmise, that 1) such a single, indivisible conception is possible only in our awareness, and that 2) it is to be perceived gradually although its form is single. Thus, Bhartrhari proposes the schema of the manifestation of sphota in such a way that the unanalyzable cognition (anupäkebyeyajñana) becomes clearer and clearer: 
VP I.83-84 (p. 149, 11.4-5, p. 150, 11.2-3):19

In the same way (just as the memory of a vedic verse or a verse in ordinary speech is strengthened by its repetition), through the unanalyzable cognitions that are in conformity with the grasping [of sphota], the [word's] own form is ascertained when the word is manifested by the sounds (dhvani). In the intellect into which the seeds are imparted by the bodily resonances (näda) and which has reached maturity through repetition, the word (the word in the mind $=$ sphota $)$ is ascertained together with the final sound.

Auto-commentary on I.84 (p. 150, 1.4-p.151, 1.1):20

[Speaker's side:] The seeds, which are instigations (bhävana $\vec{a}$ ), that are called the latent traces (samskara) fit for the clear delineation [of the understanding of the word] are deposited [on the hearer's mind], with ever increasing intensity (yathottarotkarsena) by the bodily resonances (nāda) illuminating (avadyut) the nature of the word. [Hearer's side:] After that, the particular final sound (dhvani) causes the clear image of the word's own form (sabdasvarüpa) to enter through assimilation (upagraha $=$ saba) into the mind which has attained the full maturity (paripäka) of the fitness [for the meaning] through the activation of the function (vittiläbha) of the seeds that are instigations [and] the latent traces produced by the delineation.

Different sounds are first specified by individual efforts of the speaker who intends to pronounce a particular word. The initial sound already manifests the unitary cognition in its entirety. At that point, however, it remains quite unclear as well as ambiguous, and is designated as 'unanalyzable cognition' (anupäkhyeyajñana). This in turn generates the impressions (bhävanā = samskära) or the seeds, whereby as subsequent sounds are produced, the unanalyzable cognition is made clearer and clearer. As this process is reiterated, the pronunciation of the final sound produces the cognition that embeds the utterly clear image of the word-form (sabdasvarupa), that is, sphota. In this way, the form of sphota is gradually made clearer by each impression until it is completely manifested.

Bhartrhari emphasized the close connection between the speaker and the hearer by using the terms nāda and dhvani. Sounds are derived from the speaker's utterance. They are transferred from the speaker to the hearer. As soon as the hearer perceives the physical sounds uttered by the speaker, the latent traces arise in his intellect. Bhartrihari's sphota theory therefore focuses on the communication which necessarily consists of both sides.

\section{$4 \quad$ Maṇdanamiśra's Sphoṭa Theory}

Now let us move to Mandana's sphota theory. After Bhartrihari's establishment of the theory, sphota was strictly criticized by the so-called Varnavādins, who hold phonemes as the fundamental element of the word. The Varṇavādins in the school of Mìmāmsā accept phonemes (varna) as the basic individual units of a word (sabda), even though they understand that there is no causal relationship between phonemes and the meaning, because the meaning is not understood at the time of pronunciation of each individual phoneme. That means they have to postulate another entity that conveys the meaning. Therefore, they imagine the latent impression as standing between the 
phonemes and the understanding. Against this position, Mandana insists that phonemes cannot be the cause of understanding because they have sequence and cannot co-occur. The phonemes cannot convey the meaning singly, nor can they act together. Therefore, the unified meaning cannot arise from them. In the same manner, he empathetically refutes the view that latent impressions can become the cause of the understanding of meaning, either directly or indirectly.

Though most pages of the SS are devoted to the criticism of the varna theory, in this paper we do not discuss how Maṇana responds to Kumārila's objection. In the middle of the SS, when he proposes the process of the manifestation of sphota, Maṇana explains it following Bhartṛhari's system. Let us have a look at how it is the same as or different from the VP's statement.

SS v.18 (p. 125, 11.2-3):21

Sounds, which are differentiated according to the different efforts [of articulation], illuminate the [single word] one by one (pratyekam) in the sequence of unanalysable cognition (anupäkhyeyajñana) and its impressions.

Auto-commentary on v.18 (p. 126, 1.1-p. 127, 1.1):22

To explain, the efforts [of articulation], whose various forms are being directly perceived through the function of the mind which ascertains the effort that produces (samutthäpaka) the word, always discriminate (vyaurt) sounds, by depending on (äyatamāna) [the efforts] themselves, as being based on their intrinsic nature. Therefore, different words do not always appear because they are manifested by certain (fixed) bodily resonances (nāda).

The verse says that external sounds (dhvani), which are differentiated by the efforts of articulation, manifest the word. And in the auto-commentary it is rephrased as follows: the word is revealed by the certain internal resonances (näda) which have been discriminated from the external sounds (dhvani) by means of the efforts of articulation. Mandana interprets the word vivrtta in the VP I.47 as bbinna and vyaurtta. Bhartrihari rephrased it in his auto-commentary as vikriya and präptavivarta, and therefore I took vivrtta as meaning the accumulation and transformation as its consequence. However, Mandana's understanding of the VP I.47 is slightly different from that. The word vyaurt can have the meaning not so distant from what we understand in vivrt. But by adding the prefix $\bar{a}$-, this passage suggests Mandana's own idea on the relation between dhvani and nāda, that the latter is the effect of exclusion from the former. At least, the idea of transformation from the subtle external sounds into the gross bodily resonances cannot be found in the auto-commentary.

Mandana continues the auto-commentary on v.18 as follows, which is in turn closely related to the VP I.83:

Auto-commentary on v.18 (p. 129, 1.3-p. 132, 1.1):23

Nor do other bodily resonances (itaranäda) become useless, because of the difference of the manifestation. To explain, to the hearer in whose mind specific latent impressions (bhävana have not yet arisen, the preceding sounds (pürve dhvanayah) make manifest the apprehensions (prakbyā: undifferentiated perceptions), which grasp the unclear (avyakta) form [of the word] and [at the same time] sow the seeds that are the impressions conducive (anuguna) to the 
production of a more vivid (vyaktatara) discrimination [of the word's form]. As for the final [sound], it produces the extremely clear (ativyaktatara) [final] conception, in which the image of the sphota seems to be embedded (vinivista) with full clarity assisted by all the seeds that are the latent impressions activated by the vague perceptions caused by the preceding sounds, just as when an expert in jewels is examining a jewel, its true nature (tattva) is not distinctly delineated (anupäkhyäta) when he first perceives it, but passing through an intellect (buddhi) to which specific latent impressions have been imparted by that pre-discursive cognition becomes manifest in his final mind (cetas). For otherwise clear (sphuta) manifestation would be impossible, because there would be no difference [in how it appears] before and after.

The hearer first directly perceives particular physical sounds which are uttered by the speaker. Each physical sound generates an impression in the hearer's mind, which helps the perception of the immediate sound. By means of the latent traces generated in the direct perception, the hearer internalizes those sounds as sphota. Here, we can see that the first part of the commentary is talking concisely from the perspective of the speaker about the process of the internalization of the external sounds, and then it changes the perspective to that of the hearer. The SS v.18 is in fact a concise summary of the VP I.47 (karanebhyo vivrttena dhvaninā: the speaker's perspective) and I.83 (pratyayair anupäkhyeyair grahanānugunais: the hearer's perspective). However, this summary may bring about a danger of misunderstanding dhvani. For, as we have seen before, the usages of dhvani in I.47 and I.83 are slightly different: the former is the subtle sounds pervading the ether, while the latter is the external sounds perceived by the hearer's sense-organ. And as far as I checked, Mandana gave up adopting the idea of the subtle sounds explained in the auto-commentary on I.47. Indeed, in the SS, we realize that Mandana does not talk in such detail about the perspective of the speaker. $\mathrm{He}$ refers to the speaker only as the starting point of the whole process of communication, and also when he criticizes the oneness of the speaker, which is one of the conditions of the understanding of meaning held by the Varnavādins. His interest focuses on how the hearer perceives the word, and not on how the speaker pronounces the word. And this makes a great deal of sense because "the process of understanding the word" is not relevant to the speaker: he already knows what he wants to say and makes the effort to pronounce it, and therefore for him, the existence of sphota is evident.

Concluding Remarks: Internalization of Speech

The nature of the word is its conceptual form (svarüpa). This form, or sphota, is the signifier (word) as well as the signified (referent), and is consistent (nitya $=$ siddha) as long as one belongs to a particular language community. And consequently, as long as it is called "the word," it must have meaning. Speech is internalized by the speaker at the time of pronunciation, and is transferred by him to the hearer. Focusing on the former, we see the relation between sound (näda) and the place of articulation. Focusing on the latter, on the other hand, the relation between sound (dhvani) and the auditory faculty is seen. Both are different processes but sounds are the same. By carefully seeing the usage of nāda and dhvani, we can find how Bhartrihari thought of the process of communication, that is, the circulation of sounds from subtle sound pervading in the ether to the actual sound pronounced by the speaker.

The sphota theory is the theory of how the word is perceived and understood by the hearer.

Journal of World Philosophies 2 (Summer 2017): 109-120 
Bhartrihari did not separate this as one independent theory, and therefore sphota was related with many different concepts. The fact that Maṇdana's sphotata theory does refer even minimally to nāda led scholars to the conclusion that both words are synonymous. But his discussion is certainly on the basis of the VP, and I conclude that Bhartrihari's usages are still alive in the SS.

Akane Saito, is a post-doctoral fellow (PD) at the Japan Society for the Promotion of Science (JSPS). She is currently working on 'Maṇanamiśra and His works: the Brahmasiddhi, Vidhiviveka, and Vibhramaviveka.' Her latest publication is: “The Grammarians' Concept of Śabda in Relation to the Theory of Sphoța: Aștāāhyāyī 1.2.45 and 1.1.70," South Asian Classical Studies 10, (2015):

297-335.

1 In the following, the upper case in 'Grammar,' 'Grammarian,' and 'Grammatical' has been used to refer to a Pāninian orientation.

2 K. A. Subramania Iyer, "The Doctrine of Sphota," Journal of the Ganganatha Jha Research Institute 5, (1947): 121-47; Sphotasiddbi of Mandana Miśra (English Translation) (Pune: Deccan College Post-graduate and Research Institute, 1966).

3 Joshi (1967) gives us an overview of the development of the sphota theory including an analysis of sphota given by Kauṇabhațta in $17 \mathrm{CE}$. The pre-modern Grammarians including Kaundabhațta are more focused than Bhartṛhari on the linguistic approach. For example, in discussions of meaningful components, the pre-modern Grammarians maintain that it is not the primitive elements or prototypes (sthanin) but their substitutes (àdeśa) that should be considered to be the meaning-bearing units, against the position of the Naiyayikas who insist that it is the other way around. Besides, the later Grammarians have several distinct categories of sphota which are exhaustively and minutely classified. It is, in the words of Joshi (ibid.: 75, 11.7-13), Pāninian analysis proceeding from "bottom-'to'-top," which was actually devalued by Bhartrihari as a mere postulation. See: ed. S. D. Joshi, The Sphotanimaya of Kaunda Bhatta (Pune: University of Poona, 1967).

4 John Brough, "Theories of General Linguistics in the Sanskrit Grammarians," Transactions of the Philological Society 50 (1951): 27-46; K. A. Subramania Iyer, "Bhartṛhari on Dhvani," Annals of the Bhandarkar Oriental Research Institute 46, no.1/4, (1965): 49-65. Brough (1951: 41 1.21-42, 1.14), criticizes the tendency to put some mysterious image on the concept of sphota.

5 See the MBh Paspaśāhnika (1880: 1, 11.6-13). ed. F. Kielhorn, The Vyākarana = Mahäbhäsya of Patañjali, vol. 1 (Pune: Bhandarkar Oriental Research Institute, 1880).

$6 \quad$ See the MBh on Vārttika 5 on A 1.1.70 (1880: 181, 1l.19-24).

7 A 1.1.68: svam rüpam śabdasyäśabdasamjñāal 'A linguistic element's own form (svam rüpam) is understood to refer to that element (śabdasya [samjinā '[name] of a speech unit') itself, not to signify the meaning of the item, unless the element in question is a technical term of grammar (aśabdasamjñä)' (Cardona 1988: 15, 11.1-6). George Cardona, Pānini: His Work and Its Traditions, vol. 1, Background and Introduction (Delhi: Motilal Banarsidass, 1988).

8 See the Padamañjarī on A 1.1.68 (1985: 239, 11.5-9). ed. Srīnārāyaṇa Misra, Käśsikāurtti of Jayāditya-Vämana (Along with Commentaries Vivaranapañcikā-Nyāsa of Jinendrabuddbi and 
Padamañjari of Haradatta Miśra), vol. 1, Ratnabharati Series 5 (Varanasi: Ratna Publications, 1985).

See the auto-commentary on the VP I.23 (1966: 52, 1.1-53, 1.2). ed. K. A. Subramania Iyer, Väkyapadīy of Bhartrihari with the Commentaries Vrtti and Paddhati of V rsabhadeva, vol. 1, Deccan College Monograph Series (Pune: Deccan College Postgraduate and Research Institute, 1966). This idea of equating śabdasvarüpa and sabdäkrti has been proposed by Akamatsu in his two articles, both of which are annotated Japanese translations of Bhartṛhari's other work Mahäbhäsyadīpikà I.16.26-18.5. Akamatsu focuses on the permanence of the word and, using also the VP, points out that the word's generic form (śabdäkrtit) is conceptually equivalent to śabdajāti and śabdasvarüpa. Akihiko Akamatsu (赤松 明彦), “Is the Word Permanent or Produced? - On MBhD I.16.26-18.5 - (1)," in Suguroshinjō-bakase Koki-kinen Ronbunshū, ed. Suguroshinjō-hakase Koki-kinen Ronbunshū Kankō-kai (Tokyo: Sankibo-busshorin, 1996), 157-67; "Is the Word Permanent or Produced? — On MBhD I.16.26-18.5 — (2)," Annual of Philosopby 55, (1996): 1-31.

Journal of World Philosophies 2 (Summer 2017): 109-120 
bāhyadrutādivrttikeälavyavasthām prakalpayati/ /

19 pratyayair anupäkhyeyair grahanānugunais tathäl dhvaniprakäsite sabde svarüpam avadhäryate//

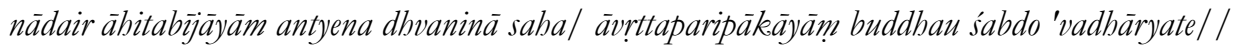

20 nādaịh sabdātmānam avadyotayadbhir yathottarotkarșenādhìyante vyaktaparicchedānugunasamskärabhāvanäbijänil tataśs cāntyo dhvaniviseșạ.

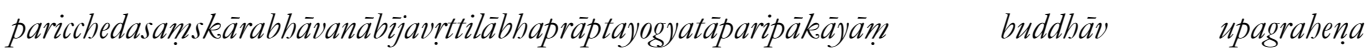
śabdasvarüpākāram samniveśayatil/

21 ed. S. K. Rāmanātha Śastrī, The Sphotasiddhi of Ācārya Mandanamisra with the Gopālikē of Rsiputra Parameśvara, Madras University Sanskrit Series, No. 6 (Madras: University of Madras, 1931).

prayatnabbedato bbinnā dhvanayo 'sya prakāsákāh/ pratyekam anupäkhyeyajnānatadbhävanākramāt/ /

22 tathā hi - sarvatra śabdasamutthäpakaprayatnanirüpanacittavrttyädhyaksam upalabbyamānarüpabhedāh prayatnāh svätmany àyatamanāh svabhävahetutaya (emended from svabhävabhedahetutaya) dhvanin vyāvartayanti, tato niyatanādanibandhanopavyañjanāh na sarvatra śabdabhedäh prakäsante/ There are numerous interpretations given in the sub-commentary with regard to the words svatmany àatamanāh svabbāvahetutayā; but in this paper I translate only in one way.

na cetaranädavaiyarthyam, abbivyaktibhedāt/ tathā hi-pürve dhvanayo 'nupajätabhävanāivisesamanasah. pratipattur avyaktarüpopagrähinịir vyaktataraparicchedotpädānugunabhävanäbijaväpiniņ̄ (vyaktatara- is emended from uttaravyakta-) prakbyāh prädurbhāvayanti, paścimas tu purastanadhvaninibandhanäryaktaparicchedaprabhāvitasakalabhāvanābìjasabakāri

sphutataravinivistasphotabimbam iva pratyayam ativyaktataram udbhävayati (emended from udbhävayanti), yathā ratnapariksinnah parīksamānasya prathamasamadhigamānupākehyätam

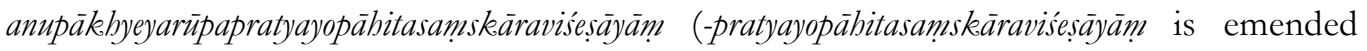
from -pratyayopähitasamskārarüpāhitavisésāyām) buddhau kramena carame cetasi cakästi ratnatattvam/ na by anyathā sphuțaprakäśa upapadyate pura iva paścād api viśsesābhāvāt/ 